Prepared in cooperation with the Wyoming Department of Environmental Quality, Wyoming Game and Fish Department, and the U.S. Department of Agriculture Forest Service, Region 2

\title{
Bankfull-Channel Geometry and Discharge Curves for the Rocky Mountains Hydrologic Region in Wyoming
}

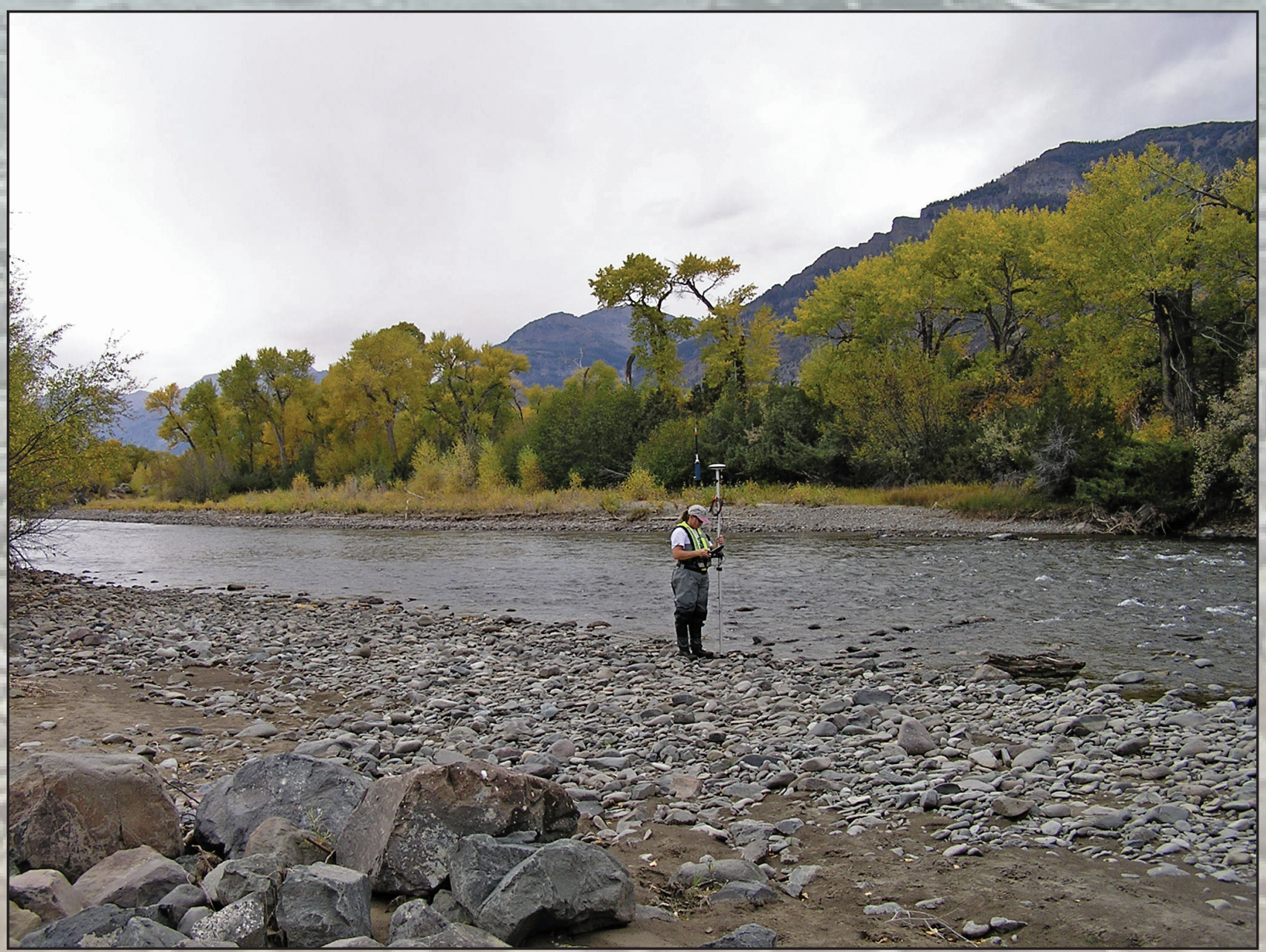

Scientific Investigations Report 2012-5178 
COVER: Kathy Foster, U.S. Geological Survey, measuring channel cross section on the East Fork Wind River near Dubois, WY, streamgage 06220500.

Photograph by Greg Boughton, U.S. Geological Survey. 


\section{Bankfull-Channel Geometry and Discharge Curves for the Rocky Mountains Hydrologic Region in Wyoming}

By Katharine Foster

Prepared in cooperation with the Wyoming Department of Environmental Quality, Wyoming Game and Fish Department, and the U.S. Department of Agriculture Forest Service, Region 2

Scientific Investigations Report 2012-5178 


\title{
U.S. Department of the Interior \\ KEN SALAZAR, Secretary \\ U.S. Geological Survey \\ Marcia K. McNutt, Director
}

\author{
U.S. Geological Survey, Reston, Virginia: 2012
}

For more information on the USGS - the Federal source for science about the Earth, its natural and living resources, natural hazards, and the environment, visit http://www.usgs.gov or call 1-888-ASK-USGS.

For an overview of USGS information products, including maps, imagery, and publications, visit http://www.usgs.gov/pubprod

To order this and other USGS information products, visit http://store.usgs.gov

Any use of trade, firm, or product names is for descriptive purposes only and does not imply endorsement by the U.S. Government.

Although this information product, for the most part, is in the public domain, it also may contain copyrighted materials as noted in the text. Permission to reproduce copyrighted items must be secured from the copyright owner.

Suggested citation:

Foster, Katharine, 2012, Bankfull-channel geometry and discharge curves for the Rocky Mountains Hydrologic Region in Wyoming: U.S. Geological Survey Scientific Investigations Report 2012-5178, 20 p. 


\section{Contents}

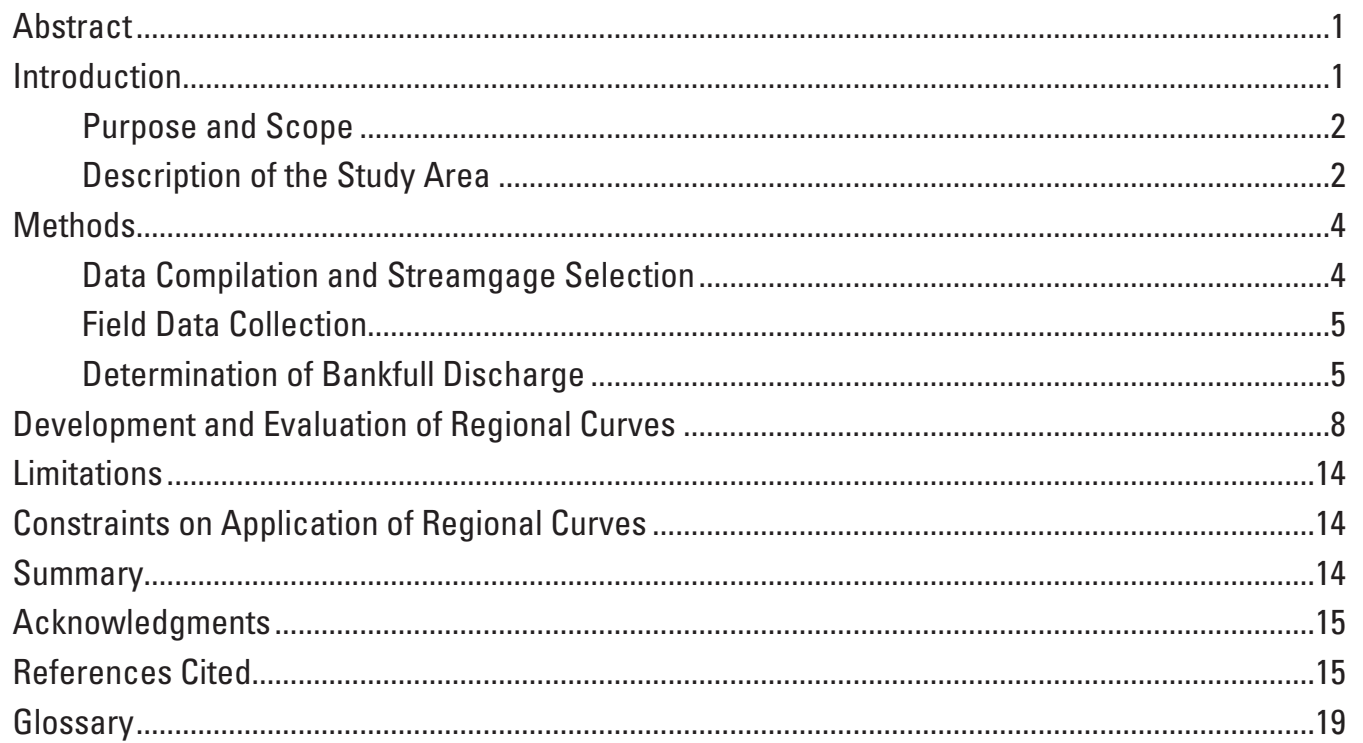

\section{Figures}

1. Surveyed streamgage location and Rocky Mountains Hydrologic Region in Wyoming......3

2. Longitudinal profile data collected at U.S. Geological Survey streamgage 06299500

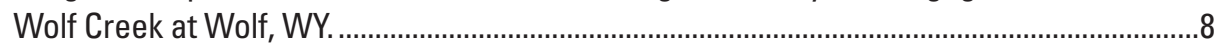

3. Regional curves representing relation between $A$, cross-sectional area, $B$, bankfull discharge, $C$, bankfull width, and $D$, bankfull depth and drainage area for the Rocky Mountains Hydrologic Region, Wyoming.

4. Regional curves representing relation between $A$, cross-sectional area, $B$, bankfull discharge, $C$, bankfull width, and $D$, bankfull mean depth and drainage area for streamgages with greater than 25 inches mean annual precipitation for the Rocky Mountains Hydrologic Region, Wyoming......

\section{Tables}

1. Surveyed streamgages, latitude, longitude, period of record, mean annual precipitation and drainage area for streams in the Rocky Mountains Hydrologic Region, Wyoming...

2. Bankfull-channel geometry data for selected streamgages in the Rocky Mountains Hydrologic Region, Wyoming .

3. Statistical results relating bankfull-channel geometry and bankfull discharge to drainage area in watersheds with less than and greater than 25 inches mean annual precipitation in the Rocky Mountains Hydrologic Region, Wyoming

4. Equations and diagnostic statistics for regional curves relating bankfull-channel geometry and bankfull discharge to drainage area for streams in the Rocky Mountains Hydrologic Region, Wyoming ... 
5. Streamgages exceeding at least one test criterion for influence and leverage for streams in the Rocky Mountains Hydrologic Region, Wyoming.

6. Equations and diagnostic statistics for regional curves relating bankfullchannel geometry and bankfull discharge to drainage area for streams with mean annual precipitation greater than 25 inches in the Rocky Mountains Hydrologic Region, Wyoming

7. Streamgages exceeding at least one test criterion for influence and leverage for streams with mean annual precipitation greater than 25 inches in the Rocky Mountains Hydrologic Region, Wyoming.

\section{Conversion Factors and Datums}

\begin{tabular}{lcl}
\hline \multicolumn{1}{c}{ Multiply } & By & To obtain \\
\hline & Length & \\
\hline inch (in.) & 25.4 & millimeter $(\mathrm{mm})$ \\
foot $(\mathrm{ft})$ & 0.3048 & meter $(\mathrm{m})$ \\
foot per foot $(\mathrm{ft} / \mathrm{ft})$ & 1.0 & meter per meter $(\mathrm{m} / \mathrm{m})$ \\
\hline & Area & \\
\hline square foot $\left(\mathrm{ft}^{2}\right)$ & 929.0 & square centimeter $\left(\mathrm{cm}^{2}\right)$ \\
square foot $\left(\mathrm{ft}^{2}\right)$ & 0.09290 & square meter $\left(\mathrm{m}^{2}\right)$ \\
square mile $\left(\mathrm{mi}^{2}\right)$ & 2.590 & square kilometer $\left(\mathrm{km}^{2}\right)$ \\
\hline & Flow rate & \\
\hline cubic foot per second $\left(\mathrm{ft}^{3} / \mathrm{s}\right)$ & 0.02832 & cubic meter per second $\left(\mathrm{m}^{3} / \mathrm{s}\right)$ \\
foot per second $(\mathrm{ft} / \mathrm{s})$ & 0.3048 & meter per second $\left(\mathrm{m}^{2} / \mathrm{s}\right)$ \\
\hline
\end{tabular}

Vertical coordinate information is referenced to the National Geodetic Vertical Datum of 1929 (NGVD29).

Horizontal coordinate information is referenced to the North American Datum of 1983 (NAD83).

Water year is the 12-month period from 0 ctober 1 through September 30 and is designated by the year in which it ends. For example, the water year ending September 30, 2009, is called water year 2009. 


\title{
Bankfull-Channel Geometry and Discharge Curves for the Rocky Mountains Hydrologic Region in Wyoming
}

\author{
By Katharine Foster
}

Abstract

Regional curves relate bankfull-channel geometry and bankfull discharge to drainage area in regions with similar runoff characteristics and are used to estimate the bankfull discharge and bankfull-channel geometry when the drainage area of a stream is known. One-variable, ordinary leastsquares regressions relating bankfull discharge, cross-sectional area, bankfull width, and bankfull mean depth to drainage area were developed from data collected at 35 streamgages in or near Wyoming. Watersheds draining to these streamgages are within the Rocky Mountains Hydrologic Region of Wyoming and neighboring states.

Data collected at each streamgage reach included one longitudinal profile of bankfull features, water surface and channel-bed elevations, one or more riffle cross-section surveys of channel geometry, and riffle and reach-average pebble counts. Various indicators were used to determine bankfullchannel geometry. Field data were analyzed to determine bankfull area, bankfull width, bankfull mean depth, $\mathrm{D}_{50}-$ and $\mathrm{D}_{84}$-particle size for each pebble count, bankfull discharge, and recurrence interval at each site.

Two sets of regional curves were developed; one for streamgages representing the range of mean annual precipitation and one for streamgages with greater than 25 inches mean annual precipitation. All regional curves presented in this report have slopes that are significantly different from zero. Drainage area explains most of the variability in crosssectional area for all streamgages and for streamgages with greater than 25 inches mean annual precipitation (coefficient of determination $\left(\mathrm{R}^{2}\right)=0.85$ and 0.91 , respectively). Drainage area explains less of the variability in bankfull discharge for all streamgages and streamgages with greater than 25 inches mean annual precipitation $\left(\mathrm{R}^{2}=0.77\right.$ and 0.87 , respectively), bankfull width $\left(\mathrm{R}^{2}=0.80\right.$ and 0.83 , respectively) and bankfull mean depth $\left(\mathrm{R}^{2}=0.48\right.$ and 0.64 , respectively). Residual standard error ranges from 24 to 56 percent for all streamgages and from 20 to 41 percent for streamgages with greater than 25 inches mean annual precipitation. Some streamgages exhibited influence, leverage, or both on all regional curves developed for the Rocky Mountains Hydrologic Region.
Limitations associated with streamgage selection and development of the curves result in some constraints for the application of regional curves presented in this report. These curves apply only to streams within the study area in watersheds having land use, streamflow regulation, and drainage areas consistent with criteria used for streamgage selection. Regional curves presented here are not intended for use as the sole method for estimation of bankfull-channel geometry characteristics; however, they may supplement field identification of the bankfull channel when used in combination with fieldverified bankfull indicators, streamflow-frequency analysis, or other supporting evidence.

\section{Introduction}

Wyoming's waters are protected to provide the highest possible water quality commensurate with their designated uses, some of which include aquatic life, drinking water, recreation, and agriculture (Wyoming Department of Environmental Quality, 2007). Streams that fully support their designated uses meet applicable water quality standards, are biologically functional, and are geomorphically stable systems. Major disruptions to stream channel stability are primarily attributed to changes in flow and(or) sediment regime caused by current (ongoing) and historic land use and watershed development activities. The cumulative effects of channel and watershed disturbance can cause persistent instability problems with long-term consequences, including: accelerated streambank erosion and lateral channel migration rates; channel degradation (incision) or aggradation (excess sediment deposition); frequent flooding; loss of land, productive soil, buildings, and road crossings; and(or), impairments to water quality, biological function, and scenic value.

Stream channels are formed and maintained by a discharge defined as the dominant or effective discharge. The effective discharge is considered to be the most effective streamflow for moving sediment, forming or changing streamchannel bars and meanders, and performs much of the work to construct a channel with the proper dimension, pattern, and profile required to efficiently process the water and sediment produced from its watershed (Wolman and Miller, 1960; 
Dunne and Leopold, 1978). Wolman and Miller (1960) initially proposed that bankfull discharge is similar to effective discharge. Andrews (1980) later verified that both are strongly correlated based on an analysis of the relation of discharge to total sediment load transport rates. Therefore, bankfull discharge is considered the same as effective discharge and is used throughout this report. Unique characteristics of the bankfull discharge and resultant channel features it creates are summarized by Andrews (1980) and Leopold (1994).

The bankfull discharge and its unique channel dimensions provide consistent measures from which channel conditions can be characterized and related to streams of similar morphology. For stable stream reaches with a well-developed flood plain, bankfull stage can be readily identified in the field from visible indicators or features. Identification and verification of bankfull discharge and its associated channel dimensions are critical steps in the channel stability assessment process and a key concept in determining departure from stream channel stability (Rosgen, 2006).

Some of the more common tools available for supporting selection of the bankfull channel are regional curves. Regional curves are one-variable, ordinary least-squares regressions relating bankfull discharge, cross-sectional area, width, and mean depth to drainage area in settings that are expected to have similar characteristics (Dunne and Leopold, 1978; Leopold, 1994). Equations describing regional curves can be used to estimate the discharge and dimensions of the bankfull channel when drainage area of the watershed is known.

Hydrologic regions or physiographic provinces are often assumed to have homogenous runoff characteristics and are commonly used to define the area that regional curves represent. A hydrologic region is an area with similar geology and climate. Miller (2003) divided Wyoming into six hydrologic regions based on similarities in peak-flow characteristics and environmental factors that influence them. Please refer to Miller (2003) for more information on how regions were delineated. Annual peak flows in mountainous areas of Wyoming typically are in response to snowmelt runoff. Annual peak flows in basins and plains areas generally are the result of rainfall runoff. Recent studies have also used hydrologic regions or physiographic provinces as a basis for developing regional curves (McCandless and Everett, 2002; Chaplin, 2005; Krstolic and Chaplin, 2007; Mulvihill and Baldigo, 2007).

The U.S. Geological Survey (USGS), Wyoming Water Science Center in cooperation with the Watershed Program of the Wyoming Department of Environmental Quality, Wyoming Department of Game and Fish, and the U.S. Department of Agriculture Forest Service, Region 2, conducted a study to collect bankfull-channel geometry and bankfull discharge data at streamgages within the Rocky Mountains Hydrologic Region in Wyoming because of the need for more information about the relation of channel geometry and stream discharge to watershed area. These data then were used to develop regional curves. Regional curves are useful aids for estimating bankfull discharge and related channel geometry at ungaged sites, particularly where field indicators of bankfull stage are not apparent, such as actively incising or degrading stream channels. The intended use of regional curves is to validate estimates of bankfull discharge needed to conduct stream channel stability analyses and classify stream types as well as other uses such as stream channel restoration (Rosgen, 2006).

\section{Purpose and Scope}

This report presents methods used, data collected, and equations describing regional curves development for the Rocky Mountains Hydrologic Region in Wyoming. Bankfullchannel geometry data were collected at 37 active and discontinued streamgages between July 2010 and September 2011. Regional curves were developed by relating cross-sectional area, bankfull discharge, bankfull width, and bankfull mean depth to drainage area through regression analysis based on precipitation zones. The data collected for this project are sufficient to categorize each survey location by use of the Rosgen stream classification system (Rosgen, 1996). Use of this classification system is not addressed in this report.

\section{Description of the Study Area}

Wyoming is located in the western United States on the edges of the Great Plains and the Rocky Mountains. Topographic relief of the State is large; altitudes range from less than 3,100 feet where the Belle Fourche River flows into South Dakota, to over 13,000 feet in the Wind River Range (fig. 1). The Continental Divide forms the crest of several of Wyoming's mountain ranges, traversing the State from southeast to northwest.

Diverse physiographic characteristics combine with regional climatic patterns to create environmental conditions that influence streamflow characteristics of Wyoming streams. Most important of these combinations are the mountain ranges of the State and two different continental-scale precipitation sources. Weather systems transporting moisture from the Pacific Ocean are the primary source of precipitation in the western part of the State. Upslope systems bring moisture from the Gulf of Mexico and are the main source of precipitation in eastern Wyoming.

Mountain ranges dominate the western two-thirds of Wyoming. The mountain ranges, because of their orientation, serve as barriers to prevailing westerly winds and southeasterly upslope winds. Air masses from lower elevations are forced up the mountain ranges by winds. Higher mountain elevations cause cooling of these air masses and moisture condensation, resulting in precipitation. The mountain ranges and the high average elevation and northerly location of the State cause most of the precipitation to occur as snow. Because of the effects of the mountain ranges, at least 70 percent of the State's waters originate as snow in the mountainous areas (Wahl, 1970; Martner, 1986; Druse, 1991; Miller, 1999; Perry and others, 2001). 


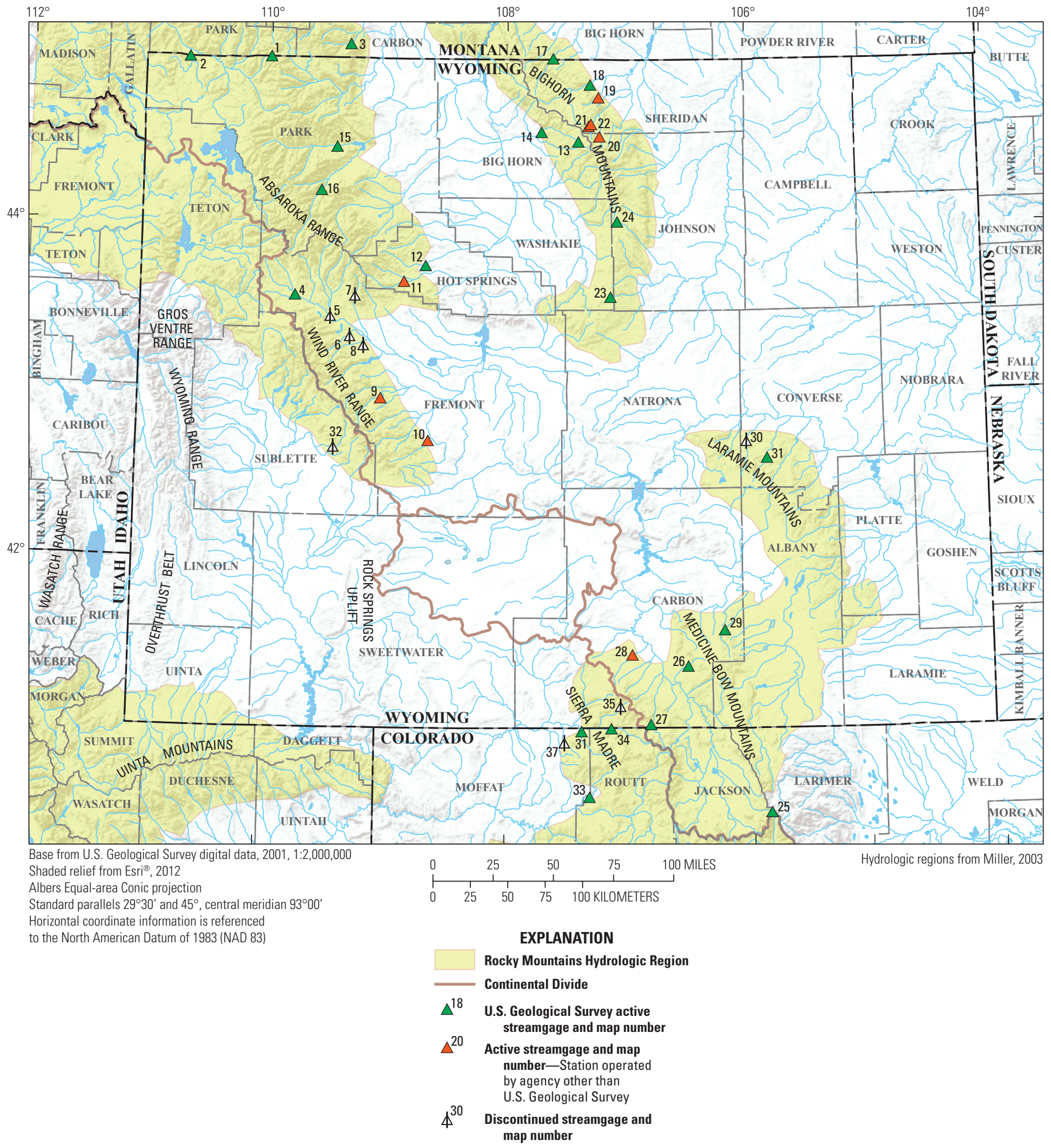

Figure 1. Surveyed streamgage location and Rocky Mountains Hydrologic Region in Wyoming. 
The Rocky Mountains Hydrologic Region incorporates most mountainous areas of Wyoming, including all ranges in northwestern Wyoming, the Wind River Range, the Bighorn Mountains, the northern Laramie Mountains, the Sierra Madre, the Medicine Bow Mountains, and the Uinta Mountains (fig. 1). These medium- to high-elevation ranges mostly are forested with some alpine areas and open woodlands. Most precipitation in these ranges occurs as snow from Pacific storm fronts during winter months. Annual peak flows generally are caused by late spring and early summer melting of winter snow accumulations. Because of the low spatial and annual variability in snow accumulations, variability also is low in the resulting annual peak flows (Miller, 2003).

\section{Methods}

Streamgages were evaluated for use in the study and annual peak flow data and basin characteristics data were compiled. Frequency analyses were completed for each streamgage in accordance with recommended methods. Regional regression equations relating bankfull-channel geometry and bankfull discharge to drainage area were developed.

\section{Data Compilation and Streamgage Selection}

Active and discontinued streamgages were evaluated to determine their suitability for inclusions in the study based on initial filtering criteria. Streamgages located in Wyoming and within 50 miles of the State were considered. Filtering criteria are intended to provide a consistent means of selecting streamgages to characterize the bankfull channel. A brief description of each criterion is provided below:

- No more than approximately 20 percent of the upstream watershed is classified as "urban" land use. This percentage was chosen for consistency with the selection criteria of White (2001), Cinotto (2003), and other efforts to develop regional curves.

- The streamgage has a period of record of at least 10 years.

- If the streamgage is discontinued, the streamgage must have been operational until at least 1993 to minimize the possibility of changes to the channel that would require redevelopment of the water-surface elevation (stage) to discharge (rating) curve. Redevelopment of ratings is beyond the scope this study.

- Streamflow at the streamgage is subjected to no greater than approximately 20 percent regulation. This percentage was chosen for consistency with the selection criteria of White (2001) and Cinotto (2003).

- A suitable length of stream reach is available to complete the field survey.

- The stream is wadeable at the time of survey.
Streamgages were selected by applying these filtering criteria to a database of active and discontinued continuous streamgages that are or were operated by the USGS in the study area. Figure 1 shows all streamgages used in the analysis, including streamgages no longer operated by the USGS. Streamgages not operated by the USGS are operated by the Wyoming State Engineers Office or local conservation or irrigation districts. The period of record, date of discontinuance, and amount of regulation of each streamgage were determined from data stored and maintained by the USGS in the Automated Data Processing System (ADAPS) of the National Water Information System (NWIS) (U.S. Geological Survey, 2009). The National Land Cover Data (NLCD) for 2001 was used to determine percent urbanization. The NLCD is a Geographic Information System (GIS) data set containing land use and land cover data (Homer and others, 2004). The percent urbanization in each watershed is defined as the sum of three land-cover classifications - low-intensity urban, medium-intensity urban, and high-intensity urban. Total urbanization ranged from 0 to 5.4 percent for all streamgages that met the initial filtering criteria. Peak-flow analysis of long-term streamflow records following guidelines from the U.S. Interagency Advisory Committee on Water Data (1982) was used to determine the annual exceedance probability (AEP) and corresponding recurrence interval of the range of streamflows observed at each streamgage. The AEP is the probability that a streamflow will be equaled or exceeded in any given year and the recurrence interval is the reciprocal of the AEP. Annual peak-flow data through water year 2010 were used for the peak-flow analysis. Hydraulic geometry curves (width, mean depth, and cross-sectional area) and mean velocity in relation to discharge were developed from streamflow-measurement data (Form 9-207 used by the USGS) for each streamgage for use in aiding identification in bankfull channel features. Form 9-207 summarizes the data pertinent to the actual discharge measurements taken over a range of flows made at a streamflow gaging station, as well as the gage height, cross-sectional area, and width associated with each discharge. The most recent water-surface elevation (stage) to discharge relation (rating) also was obtained for each streamgage.

Estimated mean annual precipitation was determined from data for the period 19712000, and obtained from the PRISM Climate Group, Oregon State University (2010). The estimates were created using the PRISM (Parameter-elevation Regressions on Independent Slopes Model) climate mapping system, developed by Daly and others (1994). PRISM is a knowledge-based system that uses point measurements of precipitation, temperature, and other climate factors to produce continuous, digital grid estimates of monthly, yearly, and event-based climate parameters.

After all data were compiled for each streamgage meeting the initial criteria, the amount of regulation was the most limiting criteria. Based on information from streamgage descriptions, many streams in Wyoming are regulated for irrigation. Irrigation may begin in the month of May, which can affect 
annual peak flows, which typically occur in late May and early June. The high elevation Rocky Mountains Hydrologic Region does not have as much regulation as other hydrologic regions in the State; therefore, this study concentrated on developing regional curves for the Rocky Mountains Hydrologic Region. A total of 74 streamgages that met the above criteria were indentified in the Rocky Mountains Hydrologic Region and 37 were selected for analysis (table 1). Sites were selected mainly based on ease of access.

\section{Field Data Collection}

A suitable reach near the streamgage was identified at each site. In general, the selected reach was about 20 bankfullchannel widths in length and, when possible, the streamgage was located in the selected reach. Within the selected reach, a longitudinal-profile survey was conducted, which includes water-surface, streambed (thalweg), and bankfull-channel elevations using a survey level, an electronic-surveying instrument (total station), or a Real Time Kinematic (RTK) survey-grade Differential Global Positioning System (DGPS). All longitudinal profile surveys were referenced to the datum established for gaging streamflow as described in the streamgage description form. At sites where the drainage area was greater than $232 \mathrm{mi}^{2}$ (drainage area ranged from $1.5 \mathrm{mi}^{2}$ to $699 \mathrm{mi}^{2}$ ), thalweg measurements were not taken because the streams were generally too deep to wade. Reaches with flow obstructions such as bridge abutments, diversion structures, and culverts were avoided, if possible.

The bankfull stage was readily identified at most sites by visual or physical bankfull indicators (Rosgen 1996). A partial listing of these indicators is:

- The presence of a flood plain at the elevation of incipient flooding.

- The elevation associated with the top of the highest depositional features (point bars or central bars within the active channel).

- A break in slope of the banks and(or) a change in particle size distribution.

- Evidence of an inundation feature such as small benches.

- Staining of rock.

- Exposed root hairs below an intact soil layer indicating exposure to erosive flows.

- Lichens and locally known riparian vegetation species.

The USDA Forest Service Stream Systems Technology Center has released a video to assist in the field identification of bankfull stage (U.S. Forest Service, 1995).

Within each selected reach, one to five riffle crosssections were surveyed. The cross-sectional surveys consisted of surveying bed and bank elevations, bankfull indicators, and the flood-prone width. Cross-sections generally were located between channel bends as described by Harrelson and others (1994), Leopold (1994), Rosgen (1996), and Powell and others (2004). The cross-section data that best represented the bankfull-channel geometry characteristics were used to provide reach-representative values of bankfull width, bankfull mean depth, cross-sectional area, width/depth ratio, and entrenchment ratio. These values are used to develop hydraulic-geometry relations and to classify the stream.

Two particle-size distributions were determined from pebble counts through the selected stream reach using methods described by Wolman (1954), Harrelson and others (1994), and Rosgen (1996). A 100-pebble count was conducted at a riffle cross section from bankfull elevation to bankfull elevation. The $\mathrm{D}_{84}$-particle size, which is defined as the particle size larger than 84 percent of the riffle cumulative sample, is used to evaluate estimated bankfull discharge values. A reachaverage pebble count was conducted to classify the reach and uses the $\mathrm{D}_{50}$-particle size, which is defined as the particle size larger than 50 percent of the reach-average cumulative sample. For the reach-average pebble count, data collection was parsed out proportionally among representative features within the longitudinal-profile reach and 10 pebbles were counted within each feature. For example, if the reach length consisted of 70-percent nonpool features or riffles and 30-percent pools, the reach-average pebble count was conducted so that 70 pebbles were counted within the nonpool features or riffles and 30 within pools. At four sites, only the cross-section related riffle pebble count was conducted (table 2).

RIVERMorph analysis software (version 4.3.0, RIVERMorph LLC, 2001-07, www.rivermorph.com) was used to analyze longitudinal-profile data. Thalweg, watersurface, and some bankfull elevations identified from crosssection surveys also were input into the longitudinal profile to provide additional bankfull data. From the input field data, a best-fit line representing the water surface and bankfull slopes through the study reach was interpolated by RIVERMorph. Measurements of riffle to riffle slope throughout the study reach and of local slope in the vicinity of cross-sections were also made using RIVERMorph. RIVERMorph also was used to analyze the cross-section survey data and to compile summary data (bankfull width, mean depth, and cross-sectional area; table 2).

\section{Determination of Bankfull Discharge}

Streamflow-measurement data (Form 9-207) were used in combination with bankfull indicators identified in the field to define the bankfull channel at each site. Bankfull features from the longitudinal profile surveys were nearly parallel to the water-surface slope (fig. 2). For active streamgages, a best-fit trend line through the longitudinal profile bankfull features was extended through the location of the streamgage (staff plate in figure 2). The elevation where the trend line crossed the location of the streamgage represents bankfull stage. The water-surface elevation (stage) that would occur in the bankfull channel and a relation between stage and discharge (rating) were used to select the discharge that corresponded to the elevation of the bankfull channel at the streamgage. This value was compared to streamflow-measurement data (Form 9-207) along with associated 


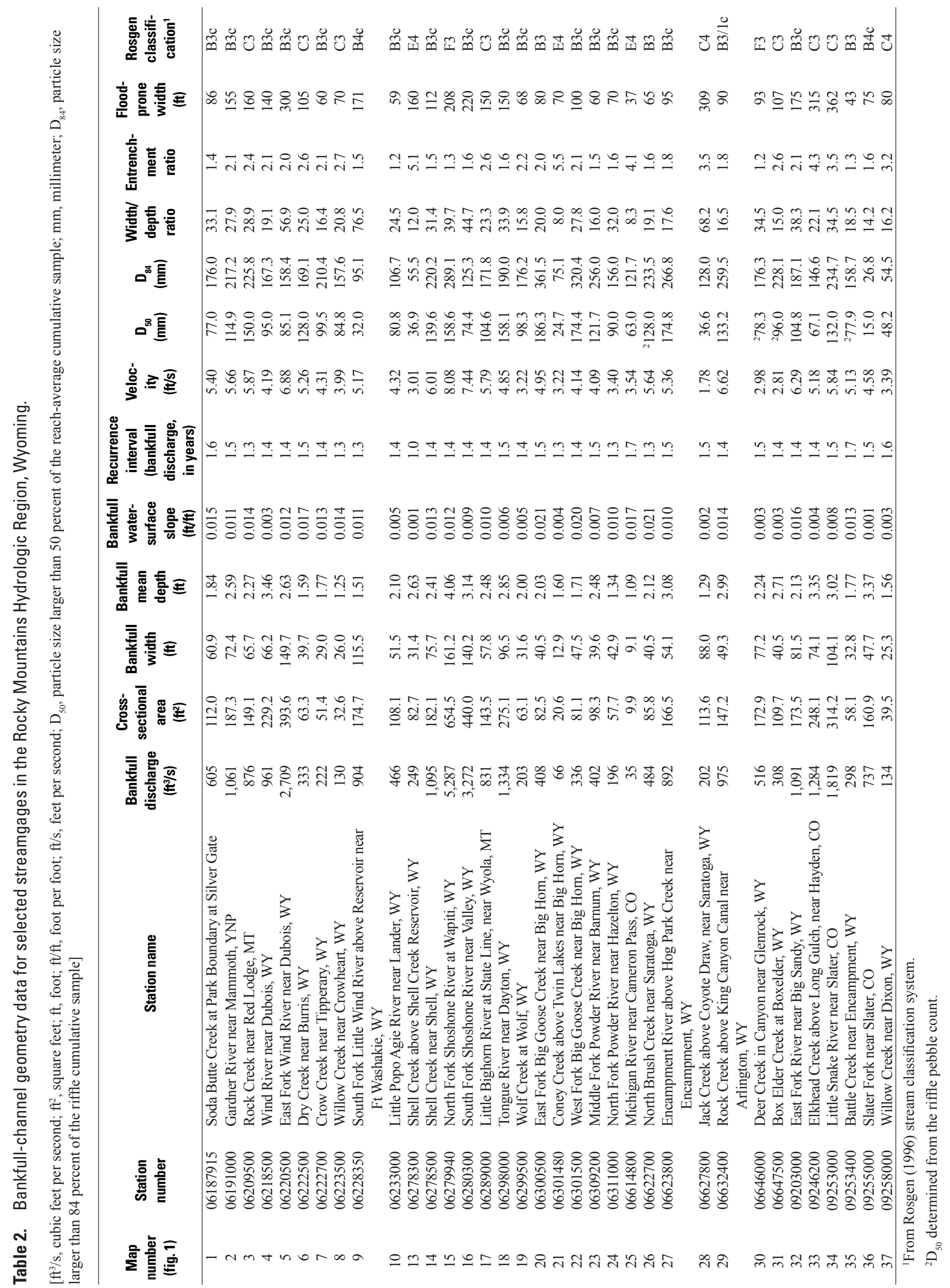




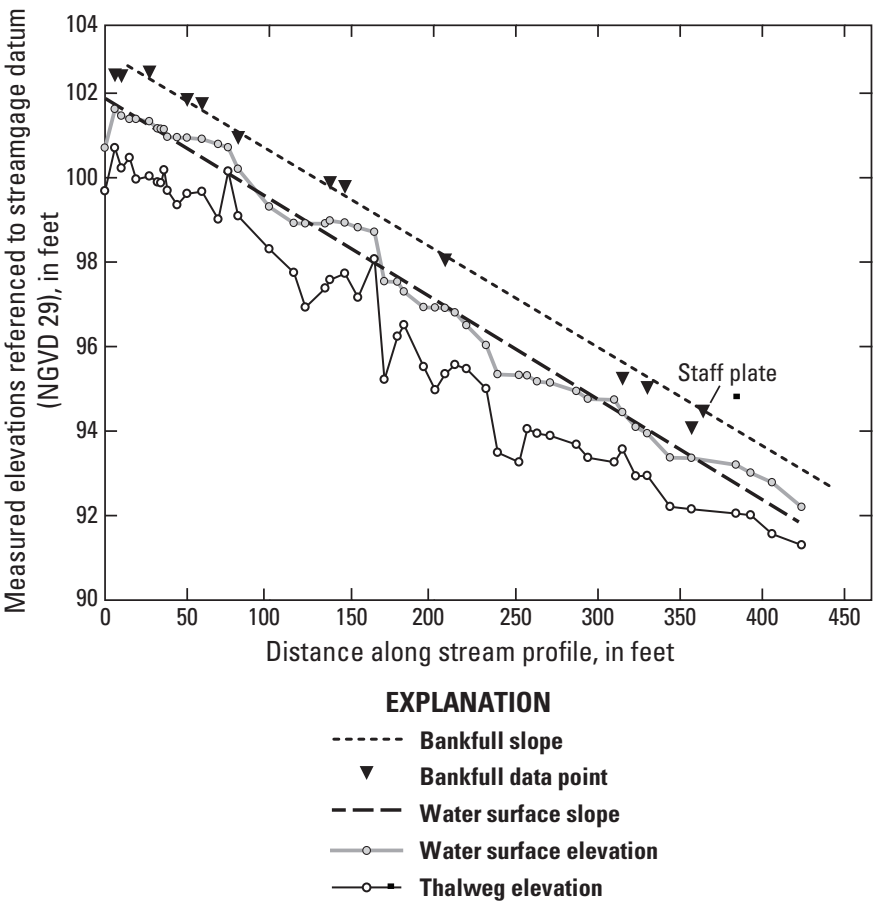

Figure 2. Longitudinal profile data collected at U.S. Geological Survey streamgage 06299500 Wolf Creek at Wolf, WY.

channel geometry characteristics. From the peak-flow analysis of long-term streamflow records, the exceedance probability and corresponding recurrence interval were determined. Then using the cross-section data that best represent the bankfull-channel geometry characteristics, bankfull discharges were determined from methods outlined in Rosgen (2008). Discharges computed from the appropriate methods at the representative cross-section were averaged to determine the bankfull discharge. The bankfull discharges determined from the stage to discharge relation were verified with the computed discharges. For inactive streamgages, the bankfull discharges were determined from methods outlined in Rosgen (2008). In all cases, the computed discharge values were used as the bankfull discharge and used for development of regional curves.

The recurrence interval of the chosen bankfull discharge was determined by comparing the bankfull discharge to a frequency distribution of annual peak discharges fit to a Pearson Type III frequency distribution (U.S. Interagency Advisory Committee on Water Data, 1982). The recurrence interval for bankfull discharge was somewhat variable from site to site and ranged from 1.0 to 1.7 years (table 2). The median recurrence interval was 1.4 years, which is similar to Chaplin (2005; 1.4 years) but more than Cinotto (2003; 1.3 years) and less than the recurrence interval (1.5 years) for bankfull discharge determined in Rosgen (1996) and Lawlor (2004).

USGS streamgages provide a source of readily available and reliable information from which regional curves can be developed. Drainage area has been determined accurately for each streamgage, and discharge measurements provide a long-term record of channel dimensions over a broad range of flows. Analysis of streamgage records provides the frequencies of occurrence for a range of streamflows. By identifying the bankfull stage at a streamgage, the investigator can determine the recurrence interval of the associated flow. Use of USGS streamflow-measurement data (Form 9-207) does not necessarily provide absolute confirmation of the bankfull channel but does support identification of the bankfull channel when used along with field indicators. Caution should be observed when using data from a USGS streamgage for geomorphic analysis because the measurement section is selected by USGS personnel to provide accurate velocity and area determinations for the computation of streamflow only. These measuring sections may be in slow-velocity, pool-dominated sections and not in riffles as required by most computations involved in fluvial geomorphology. Therefore, the user of these data should review streamgage descriptions carefully to establish whether the measurement section used by USGS personnel is a riffle, run, pool, or glide, because the methodology used to determine bankfull discharge uses riffle cross-sections and if USGS measurement are not taken in a riffle comparisons may be difficult.

\section{Development and Evaluation of Regional Curves}

Studies by Emmett (1975) and Dunne and Leopold (1978) have shown that bankfull-channel geometry characteristics and bankfull discharge are related to the size of drainage area. In regions where hydrologic processes and climate are similar, regression analysis of the relation between these bankfull channel-geometry characteristics and drainage area and bankfull discharge and drainage area for gaged streams can provide a means of estimating bankfull-channel geometry and bankfull discharge for ungaged streams when the drainage area is known. These curves can be used as a means of validating bankfull indicators observed in the field as well as estimates of bankfull discharge and associated channel geometry.

Analysis of 37 surveyed streamgages in the Rocky Mountains Hydrologic Region in Wyoming indicated that streamgage 06260000 South Fork Owl Creek near Anchor, WY (table 1) had a small amount of flow for its watershed area. Anchor Reservoir is known for its inability to hold water because of substantial seepage loses presumably from sinkholes associated with the underlying geology (Nelson Engineering, 2004). The Madison Limestone formation is prevalent throughout the upper Owl Creek basin (Love and others, 1979; Ogle, 1992). Streams draining watersheds underlain by carbonate bedrock commonly experience underflow and storage within karst features (Chaplin, 2005). As a result, these streams commonly have lower peak flows than streams in watersheds without carbonate bedrock (White, 1976; Stuckey and Reed, 2000). Therefore, this site was not used to develop regional curves. 
Another site omitted from the development of regional curves was 06265337 Cottonwood Creek at High Island Ranch near Hamilton Dome (table 1). This site is listed as being in the Rocky Mountains Hydrologic Region in Miller (2003) but upon further investigation, including the rather low mean annual precipitation, it was determined to be in a different hydrologic region. Therefore, this site was not used to develop regional curves.

Another site that needs mentioning in the development of regional curves is 06278300 Shell Creek above Shell Creek Reservoir, WY. Even though the bankfull discharge estimate at Shell Creek did not fall within an expected recurrence interval relative to other sites with similar precipitation and drainage area (table 2) because the peak flow values used to develop the streamflow-frequency curve were suspect at this site, confidence is high that an accurate bankfull discharge was obtained.

Simple linear regression techniques were used to develop regional curves for the Rocky Mountains Hydrologic Region. A computer-based statistics package, S-PLUS (TIBCO Software, Inc., 2008), was used for statistical analyses and graphics. Response variables - bankfull discharge, crosssectional area, bankfull width, and bankfull mean depth for the 35 sites used to develop regional curves (table 2)-were regressed against the explanatory variable - drainage area (table 1) - to show the relation between drainage area and each of the variables. The relation between drainage area and each response variable was described by fitting a power function with a best-fit line through the data points for each parameter using the least-squares method. The power functions are plotted on a log-log scale.

Computation of the diagnostics required transformation of the regional curves from commonly reported power functions (Dunne and Leopold, 1978; White, 2001; Cinotto, 2003) to log-linear functions. For the sole purpose of computing diagnostic statistics, each power function of the general form $y=a(D A) b$ was transformed to the form:

$$
\log (y)=\log (a)+(b \times \log (D A))
$$

where

$$
\begin{aligned}
& \log \text { is the logarithm to base } 10 \text {, } \\
& y \text { is the bankfull-response variable, } \\
& a \text { is the intercept of the regression line, } \\
& b \text { is a coefficient of regression representing the } \\
& \text { slope of the regression line, and } \\
& D A \quad \text { is the drainage area. }
\end{aligned}
$$

Annual precipitation variation of 5 inches (in.) or more can have a large influence on regional relations (Dunne and Leopold, 1978; Leopold, 1994); mean annual precipitation ranged from 20.5 in. to $48.6 \mathrm{in}$. for the entire study area. Statistical procedures that test for the differences in regional curves between precipitation zones provide a means to determine if there is justification for separate relations. A significant difference in slope or intercept would indicate that separate curves are appropriate.

To ensure that regional curves relating bankfull-channel geometry and bankfull discharge to drainage area alone would include the effects of mean annual precipitation, each streamgage was assigned an index number of 0 , or 1 , depending upon the value of mean annual precipitation at the site. All streamgages having a mean annual precipitation of less than 25 in. were given an index number of 0 , and all streamgages having mean annual precipitation greater than 25 in. were given an index number of 1 . The results of an ordinary leastsquares stepwise-regression analysis indicate that the difference between less than and greater than 25 in. mean annual precipitation is significant ( $\mathrm{p}$-values less than 0.05 ) for the slope for bankfull cross-sectional area and bankfull mean depth but not for the slope for bankfull width (table 3). Given that regressions for the other bankfull-channel geometry and bankfull discharge are significant, there would be little to no confidence and power achieved by developing separate bankfull width regressions.

Regional curves for the Rocky Mountains Hydrologic Region (35 streamgages) and for streamgages with greater than 25 in. mean annual precipitation within the Rocky Mountains Hydrologic Region (29 streamgages), were developed (fig. $3 A$ through $D$ and fig. $4 A$ through $D$, respectively). Precipitation ranges of less than 25 in., 25.1 to 30 in., 30.1 to $35 \mathrm{in}$. and greater than 35 in. mean annual precipitation are presented on figures 3 and 4 . Regional curves for streamgages with less than 25 in. mean annual precipitation were not presented because the small sample size provided poor relations.

The power functions that relate the variables of crosssectional area, bankfull discharge, bankfull width, and bankfull mean depth to drainage area for streamgages representing the Rocky Mountains Hydrologic Region are illustrated in figure $3 A$ through $D$. Table 4 gives the equations and diagnostic statistics for each regression. These regional curves show the 95-percent prediction intervals for individual estimates

\begin{tabular}{|c|c|c|c|c|c|c|c|}
\hline \multirow{2}{*}{\multicolumn{2}{|c|}{$\begin{array}{c}\text { Bankfull } \\
\text { cross-sectional area } \\
p \text {-value }\end{array}$}} & \multirow{2}{*}{\multicolumn{2}{|c|}{$\begin{array}{c}\begin{array}{c}\text { Bankfull } \\
\text { discharge }\end{array} \\
\text { p-value }\end{array}$}} & \multirow{2}{*}{\multicolumn{2}{|c|}{$\begin{array}{c}\begin{array}{c}\text { Bankfull } \\
\text { width }\end{array} \\
\text { p-value }\end{array}$}} & \multirow{2}{*}{\multicolumn{2}{|c|}{$\begin{array}{c}\text { Bankfull } \\
\text { mean depth } \\
\text { p-value }\end{array}$}} \\
\hline & & & & & & & \\
\hline Intercept & Slope & Intercept & Slope & Intercept & Slope & Intercept & Slope \\
\hline
\end{tabular}
of the response variable. Prediction intervals represent a 95-percent certainty that an individual observed value of $y$ for a given $x$ will fall within the upper and lower limits of the interval (Helsel and Hirsch, 2002). These regional curves also

Table 3. Statistical results relating bankfull-channel geometry and bankfull discharge to drainage area in watersheds with less than and greater than 25 inches mean annual precipitation in the Rocky Mountains Hydrologic Region, Wyoming. 

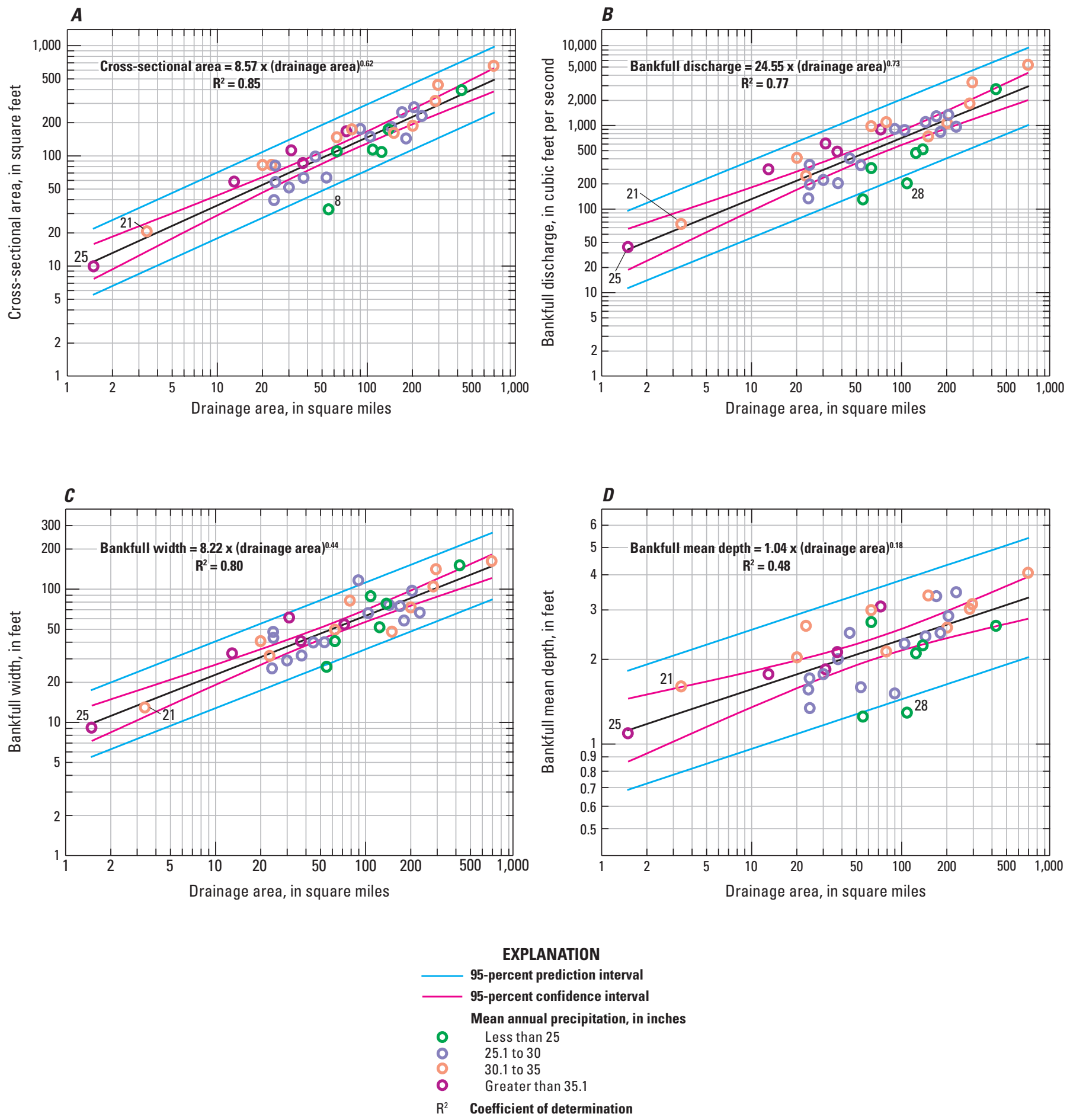

Figure 3. Regional curves representing relation between $A$, cross-sectional area, $B$, bankfull discharge, $C$, bankfull width, and $D$, bankfull depth and drainage area for the Rocky Mountains Hydrologic Region, Wyoming. 

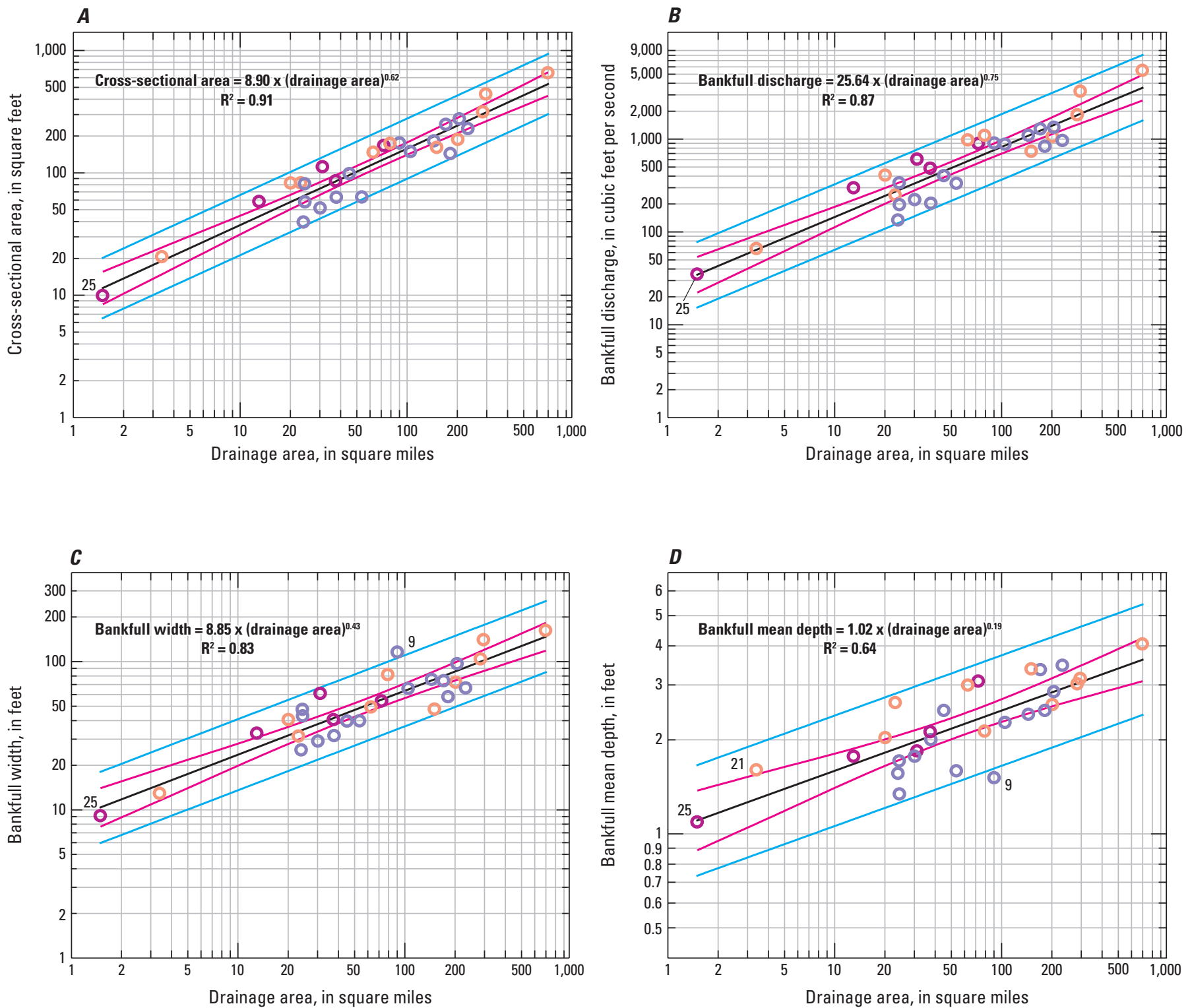

\section{EXPLANATION}

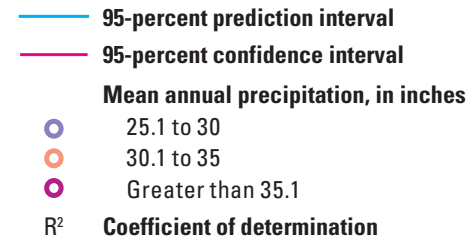

Figure 4. Regional curves representing relation between $A$, cross-sectional area, $B$, bankfull discharge, $C$, bankfull width, and $D$, bankfull mean depth and drainage area for streamgages with greater than 25 inches mean annual precipitation for the Rocky Mountains Hydrologic Region, Wyoming. 
Table 4. Equations and diagnostic statistics for regional curves relating bankfull-channel geometry and bankfull discharge to drainage area for streams in the Rocky Mountains Hydrologic Region, Wyoming.

$\left[\mathrm{R}^{2}\right.$, coefficient of determination; CSA, cross-sectional area; DA, drainage area; <, less than; Q, bankfull discharge; W, bankfull width; D, bankfull mean depth]

\begin{tabular}{|c|c|c|c|c|c|}
\hline Equa & $\mathbf{R}^{2}$ & $\begin{array}{c}\text { Residual } \\
\text { standard } \\
\text { error } \\
\text { (log } \\
\text { units) }\end{array}$ & $\begin{array}{l}\text { Residual } \\
\text { standard } \\
\text { error } \\
\text { (percent) }\end{array}$ & $\begin{array}{l}\text { p-value } \\
\text { for } \\
\text { regression } \\
\text { slope }^{2}\end{array}$ & $\begin{array}{l}\text { p-value } \\
\text { for GOF }\end{array}$ \\
\hline$\overline{\mathrm{CS}}$ & 0.85 & 0 & & & \\
\hline$Q=24.55$ & 7 & 0 . & 56 & & \\
\hline $\mathrm{W}=8.22 \times(\mathrm{DA})^{0.44}$ & 0.80 & 0.123 & 29 & $<0.0001$ & 0.960 \\
\hline $\mathrm{D}=1.04 \times(\mathrm{DA})^{0.18}$ & 0.48 & 0.104 & 24 & $<0.0001$ & 0.628 \\
\hline
\end{tabular}

${ }^{1}$ Residual standard error in percent determined from methods described by Tasker (1978).

${ }^{2} \mathrm{~A}$ p-value of less than or equal to 0.05 indicates that the slope of the regression line is different from zero.

${ }^{3}$ Kolmogorov-Smirnov Goodness of Fit (GOF) tests the regression model assumption that residuals fit a normal distribution. This test is not a representation of how well the regression line fits the data. A p-value greater than 0.05 indicates that regression residuals are normally distributed (fail to reject the null hypothesis).

show the 95-percent confidence intervals (fig. $3 A$ through $D$ ). Confidence interval represents a band within which there is a 95-percent probability that estimates of the mean bankfullchannel geometry or bankfull discharge for a particular drainage area will be observed.

Regional curves for streamgages representing the Rocky Mountains Hydrologic Region (fig. $3 A$ through $D$ ) have slopes that are significantly different than zero (p-values are less than 0.05 ; table 4 ) and normally distributed residuals (p-values from Kolmogorov-Smirnov Goodness of Fit tests are greater than 0.05 ; table 4 ) that vary randomly with drainage area. Values of DFFITS, a measure of the influence in the $y$ direction by each streamgage, indicate that streamgage 06223500 Willow Creek near Crowheart, WY has a high influence on the crosssectional area regional curve (fig. $3 A$; table 5), and streamgage 062627800 Jack Creek above Coyote Draw near Saratoga, WY has a high influence on the regional curves for bankfull discharge and bankfull mean depth (fig. $3 B$ and $D$; table 5). Streamgages 06301480 Coney Creek above Twin Lakes near Big Horn, WY and 06614800 Michigan River near Cameron Pass, $\mathrm{CO}$ have high leverage, potential of exerting strong influence on the regression slope in the $x$ direction, on all regional curves developed for streamgages representing the Rocky Mountains Hydrologic Region (fig. $3 A$ through $D$; table 5). This is probably because they have such small drainage areas. Residual standard errors, expressed in percent by methods described by Tasker (1978), ranged from 24 to 56 percent (table 4).

Coefficients of determination $\left(\mathrm{R}^{2}\right)$ indicate that 85,77 , and 80 percent of variation in cross-sectional area, bankfull discharge, and bankfull width, respectively, is explained by drainage area compared to 48 percent of the variation in bankfull mean depth (table 4). Wider 95-percent confidence intervals for bankfull mean depth (fig. $3 D$ ) reflect greater uncertainty in estimates of regression parameters for this relation compared to the other regional curves (fig. $3 A, B$ and $C$ ). Thus, regional curves are more reliable for estimation of crosssectional area, bankfull discharge, and bankfull width than bankfull mean depth for streamgages representing the Rocky Mountains Hydrologic Region.

The power functions that relate the variables of crosssectional area, bankfull discharge, bankfull width, and bankfull mean depth to drainage area representing streamgages with greater than 25 in. mean annual precipitation for the Rocky Mountains Hydrologic Region are illustrated in figure $4 A$ through $D$. Table 6 gives the equations and diagnostic statistics for each regression. These regional curves show the 95-percent prediction intervals and the 95-percent confidence intervals (fig. $4 A$ through $D$ ).

Regional curves representing streamgages with greater than 25 in. mean annual precipitation in the Rocky Mountains Hydrologic Region (fig. $4 A$ through $D$ ) have slopes that are significantly different than zero (p-values are less than 0.05 ; table 6) and normally distributed residuals (p-values from Kolmogorov-Smirnov Goodness of Fit tests are greater than 0.05 ; table 6 ) that vary randomly with drainage area. Values of DFFITS indicate that streamgages 062228350 South Fork Little Wind River above Reservoir near Ft. Washakie, WY and 06301480 Coney Creek above Twin Lakes near Big Horn, WY have a high influence on the bankfull mean depth regional curve (fig. 4D; table 7). Streamgage 062228350 South Fork Little Wind River above Reservoir near Ft. Washakie, WY also has a high influence on the bankfull width regional curve (fig. 4C; table 7). Streamgage 06614800 Michigan River near Cameron Pass, $\mathrm{CO}$ has high leverage on all regional curves for streamgages with greater than 25 in. mean annual precipitation in the Rocky Mountains Hydrologic Region (fig. $4 \mathrm{~A}$ through $D$; table 7). Residual standard errors ranged from 20 to 41 percent (table 6).

Coefficients of determination $\left(\mathrm{R}^{2}\right)$ indicate that 91,87 , and 83 percent of variation in cross-sectional area, bankfull discharge, and bankfull width, respectively, is explained by drainage area compared to 64 percent of the variation in bankfull mean depth (table 6). Wider 95-percent confidence intervals for bankfull mean depth regional curve (fig. $4 D$ ) reflect greater uncertainty in estimates of regression parameters for this relation compared to cross-sectional area (fig. $4 A$ ), bankfull discharge (fig. 4B), and bankfull width (fig. 4C) relations. Thus, regional curves are more reliable for estimation of cross-sectional area, bankfull discharge, and bankfull width than bankfull mean depth for streamgages with greater than 25 in. mean annual precipitation in the Rocky Mountains Hydrologic Region. This is consistent with other studies (Chaplin, 2005; Krstolic and Chaplin, 2007; Mulvihill and Baldigo, 2007). 
Table 5. Streamgages exceeding at least one test criterion for influence and leverage for streams in the Rocky Mountains Hydrologic Region, Wyoming.

$[--$, not applicable $]$

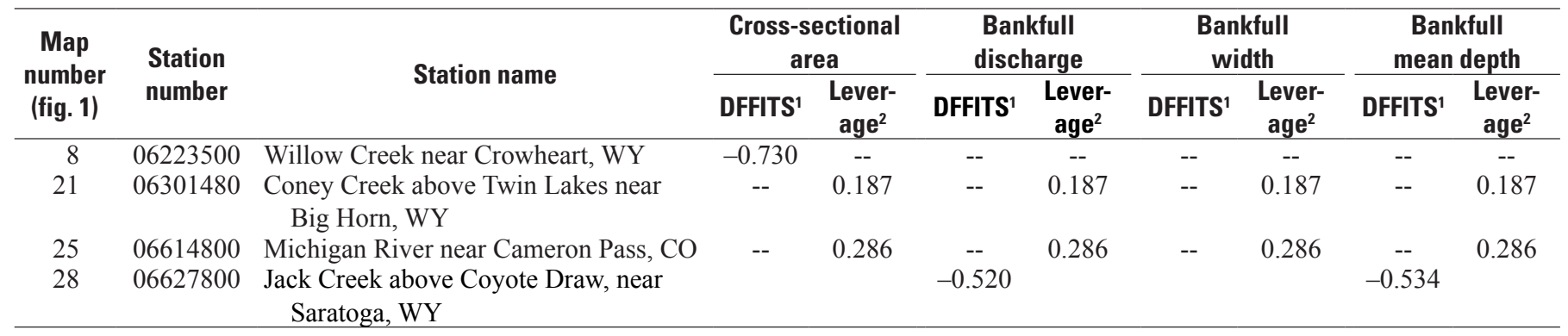

${ }^{1}$ DFFITS is a statistical term that measures the influence in the $y$ direction that each streamgage has on the regression relation (Helsel and Hirsch, 2002). A streamgage is considered to have high influence if the absolute value of DFFITS is greater then 0.478.

${ }^{2}$ Leverage is a measure of an "outlier" in the $x$ direction. A high leverage point has the potential of exerting a strong influence on the regression slope (Helsel and Hirsch, 2002). A streamgage is considered to have high leverage if greater than 0.171 .

Table 6. Equations and diagnostic statistics for regional curves relating bankfull-channel geometry and bankfull discharge to drainage area for streams with mean annual precipitation greater than 25 inches in the Rocky Mountains Hydrologic Region, Wyoming.

$\left[\mathrm{R}^{2}\right.$, coefficient of determination; CSA, cross-sectional area; DA, drainage area; <, less than; Q, bankfull discharge; W, bankfull width; D, bankfull mean depth]

\begin{tabular}{|c|c|c|c|c|c|}
\hline Equation & $\mathbf{R}^{2}$ & $\begin{array}{c}\text { Residual } \\
\text { standard error } \\
\text { (log units) }\end{array}$ & $\begin{array}{c}\text { Residual } \\
\text { standard error } \\
\text { (percent) }^{1}\end{array}$ & $\begin{array}{l}\text { p-value for } \\
\text { regression slope }\end{array}$ & $\begin{array}{l}\text { p-value } \\
\text { for GOF }\end{array}$ \\
\hline $\mathrm{CSA}=8.90 \times(\mathrm{DA})^{0.62}$ & 0.91 & 0.119 & 28 & $<0.0001$ & 0.713 \\
\hline $\mathrm{W}=8.85 \times(\mathrm{DA})^{0.43}$ & 0.83 & 0.117 & 27 & $<0.0001$ & 0.913 \\
\hline $\mathrm{D}=1.02 \times(\mathrm{DA})^{0.19}$ & 0.64 & 0.086 & 20 & $<0.0001$ & 0.608 \\
\hline
\end{tabular}

${ }^{1}$ Residual standard error in percent determined from methods described by Tasker (1978).

${ }^{2} \mathrm{~A} \mathrm{p}$-value of less than or equal to 0.05 indicates that the slope of the regression line is different from zero.

${ }^{3}$ Kolmogorov-Smirnov Goodness of Fit tests the regression model assumption that residuals fit a normal distribution. This test is not a representation of how well the regression line fits the data. A p-value greater than 0.05 indicates that regression residuals are normally distributed (fail to reject the null hypothesis).

Table 7. Streamgages exceeding at least one test criterion for influence and leverage for streams with mean annual precipitation greater than 25 inches in the Rocky Mountains Hydrologic Region, Wyoming.

[--, not applicable]

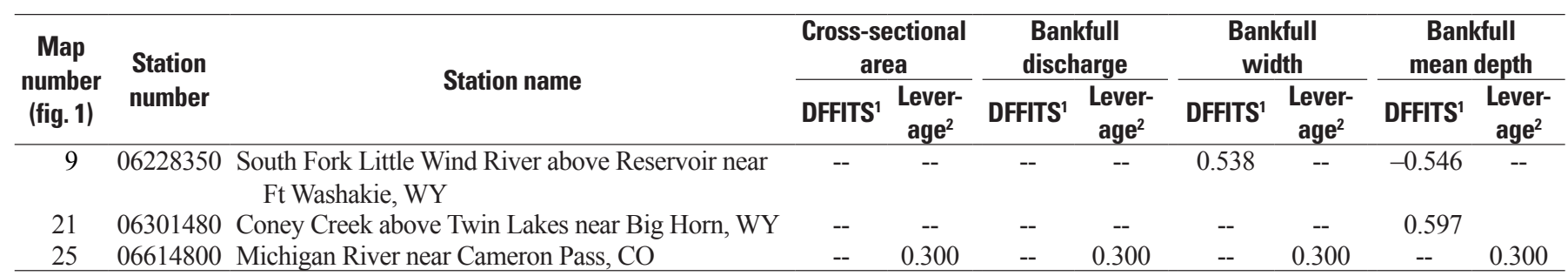

${ }^{1}$ DFFITS is a measure of the influence in the $y$ direction that each streamgage has on the regression relation (Helsel and Hirsch, 2002). A streamgage is considered to have high influence if the absolute value of DFFITS is greater then 0.525 .

${ }^{2}$ Leverage is a measure of an "outlier" in the $x$ direction. A high leverage point has the potential of exerting a strong influence on the regression slope (Helsel and Hirsch, 2002). A streamgage is considered to have high leverage if greater than 0.207. 


\section{Limitations}

Bankfull-channel geometry and bankfull discharge data are inherently variable. Regional curves use drainage area to explain this variability and are described by a best-fit equation that can be used to estimate bankfull-channel geometry characteristics and bankfull discharge. The quality of these estimates depends on how well the population is represented (number of streamgages available and their relative drainage areas) and variability caused by factors other than drainage area. The small number of streamgages used for analysis is a major limiting factor in the strength of results of this investigation. Streams with drainage areas less than $25 \mathrm{mi}^{2}$ are underrepresented in the data set. Additional bankfull discharge and bankfull-channel geometry data from small watersheds might reduce the influence of small watersheds, increase confidence, and generally improve the regional curves.

Regional curves developed for this study should only be used to confirm the bankfull channel for streams in the Rocky Mountains Hydrologic Region. Land use and other basin characteristics upstream from the reach in consideration should be similar to those used for selection criteria in this assessment. The stability of the reaches included in this study - in terms of sediment transport, hydraulic conveyance, and degradation and(or) aggradation of the stream reacheshas not been confirmed, and long-term monitoring of the reaches has not been completed. Stream channels in transitional states may have introduced increased variance into the regional curves.

\section{Constraints on Application of Regional Curves}

The limitations presented above result in some constraints for the application of regional curves presented in this report. These constraints are briefly described below:

1. Regional curves apply only to streams within the study area draining watersheds no larger or smaller than the range of watershed areas used to develop the curves.

2. Regional curves apply to streams in watersheds having land use and streamflow that is consistent with criteria used for streamgage selection.

3. None of the regional curves are intended as the sole tool for estimation of bankfull-channel geometry characteristics but may supplement field identification of the bankfull channel when used in conjunction with field-verified bankfull indicators, streamflow-frequency analysis, or other supporting evidence.

\section{Summary}

The USGS, in cooperation with the Watershed Program of the Wyoming Department of Environmental Quality, the Wyoming Department of Game and Fish, and the U.S. Department of Agriculture Forest Service, Region 2, developed bankfull regional curves for the Rocky Mountains Hydrologic Region of Wyoming in 20102011. These regional curves are one-variable, ordinary least-squares regressions relating bankfull discharge, cross-sectional area, bankfull width, and bankfull mean depth to drainage area in settings that have similar runoff characteristics. Equations describing regional curves can be used to estimate the discharge and geometry of the bankfull channel when the drainage area of the stream is known.

Bankfull-channel geometry and bankfull discharge data were collected at 37 streamgages and associated stream reaches (sites) in or near Wyoming. Data from streamgage 06260000 South Fork Owl Creek near Anchor, WY was not used in the development of regional curves because it did not exhibit the expected relation between runoff and watershed size, probably because of the underlying limestone geology in the drainage basin. Data from streamgage 06265337 Cottonwood Creek at High Island Ranch near Hamilton Dome was not used in the development of regional curves because upon further investigation, including the rather low mean annual precipitation, it was determined to be in a different hydrologic region. All sites represent drainages that are in the Rocky Mountains Hydrologic Region. Drainage areas, for the 35 sites used in the analysis, ranged from $1.5 \mathrm{mi}^{2}$ to $699 \mathrm{mi}^{2}$ and mean annual precipitation ranged from 20.5 in. to 48.6 in.

Field-data collection included one longitudinal profile, one or more cross-section surveys of bankfull-channel geometry, one pebble count at a riffle cross section, and one reach-average pebble count at most streamgages. Field data were analyzed to determine bankfull area, bankfull width, bankfull mean depth, $\mathrm{D}_{50}$ - and $\mathrm{D}_{84}$-particle size for each pebble count, bankfull discharge and return interval at each site. RIVERMorph analysis software (version 4.3.0, RIVERMorph LLC, 2001-07, www.rivermorph.com) was used to analyze the data.

Simple linear regression techniques were used to develop regional curves for the Rocky Mountains Hydrologic Region in Wyoming. Cross-sectional area, bankfull width, bankfull mean depth, and estimated bankfull discharge - the response variables - were regressed against drainage areathe explanatory variable - to show the relation between drainage area and each response variable. Two sets of regional curves were developed for each response variable based on the range of mean annual precipitation for all streamgages and for streamgages with greater than 25 in. mean annual precipitation. The relatively high coefficient of determination $\left(\mathrm{R}^{2}\right)$ value for all streamgages and streamgages with greater than 25 in. mean annual precipitation ( 0.85 and 0.91 , respectively) 
for cross-sectional area indicates that it has the strongest relation to drainage area of the parameters measured. For all streamgages the $\mathrm{R}^{2}$ values for the other geometry parameters indicate that 77 percent, 80 percent, and 48 percent of the variability in each regional curve was explained by drainage area for bankfull discharge, bankfull width, and bankfull mean depth, respectively. For streamgages with greater than 25 in. mean annual precipitation the $\mathrm{R}^{2}$ values for the other geometry parameters indicate that 87 percent, 83 percent, and 64 percent of the variability in each regional curve was explained by drainage area for bankfull discharge, bankfull width, and bankfull mean depth, respectively. Residual standard error ranged from 24 to 56 percent for all streamgages and ranged from 20 to 41 percent for streamgages with greater than 25 in. mean annual precipitation. Streamgage 06223500 Willow Creek near Crowheart, WY has a high influence on the cross-sectional area regional curve for all streamgages, and streamgage 06627800 Jack Creek above Coyote Draw near Saratoga, WY has a high influence on the regional curves for bankfull discharge and bankfull mean depth for all streamgages. Streamgages 06301480 Coney Creek above Twin Lakes near Big Horn, WY and 06614800 Michigan River near Cameron Pass, CO have high leverage on all regional curves for all streamgages. Streamgages 06228350 South Fork Little Wind River above Reservoir near Ft. Washakie, WY and 06301480 Coney Creek above Twin Lakes near Big Horn, WY have high influence on the bankfull mean depth regional curve for streamgages with greater than 25 in. mean annual precipitation. Streamgage 06228350 South Fork Little Wind River above Reservoir near Ft. Washakie, WY also has a high influence on the bankfull width regional curve for streamgages with greater then 25 in. mean annual precipitation. Streamgage 06614800 Michigan River near Cameron Pass, CO has high leverage on all regional curves for streamgages with greater than 25 in. mean annual precipitation.

Regional curves provide an estimate of bankfullchannel geometry and serve as tools for field identification of bankfull features. They can be used in stream assessments of ungaged streams as a guide for identifying the expected natural-channel geometry in those streams. The bankfull regional curves developed are applicable to the Rocky Mountains Hydrologic Region of Wyoming. Regional curves presented here are not intended as the sole tool for estimation of bankfull-channel geometry characteristics. Instead, they may supplement field identification of the bankfull channel when used in combination with field-verified bankfull indicators, streamflow frequency analysis, or other supporting evidence.

\section{Acknowledgments}

Many parties supported this investigation. Special thanks are due to the Wyoming Department of Environmental Quality (WDEQ), Watershed Program. Additional support also was provided by the Wyoming Game and Fish Department and the U.S. Department of Agriculture Forest Service, Region 2. Recognition is due to Lanny Goyn and Jeremy Zumberge of WDEQ for taking time out of their schedules to help collect data and provide technical support. The author thanks Scott Edmiston, Laura Hallberg, Clint Masters, and Joe Villa of USGS for providing field assistance during data collection. The author also thanks David Spidelbach and Michael Geenen of Stantec for their advice and assistance with GPS data collection and data analysis. In addition the author also thanks the colleague reviewers, Sean M. Lawlor, Christiane I. Mulvihill, and Peter J. Cinotto for thorough, technical reviews of this report.

\section{References Cited}

Andrews, E.D., 1980, Effective and bankfull discharges of streams in the Yampa River Basin, Colorado and Wyoming: Journal of Hydrology, v. 46, p. 311-330.

Chaplin, J.J., 2005, Development of regional curves relating bankfull-channel geometry and discharge to drainage area for streams in Pennsylvania and selected areas of Maryland: U.S. Geological Survey Scientific Investigations Report 2005-5147, 34 p.

Cinotto, P.J., 2003, Development of regional curves of bankfull-channel geometry and discharge for streams in the non-urban, Piedmont Physiographic Province, Pennsylvania and Maryland: U.S. Geological Survey Water-Resources Investigations Report 2003-4014, 27 p.

Daly, C., Neilson, R.P., and Phillips, D.L., 1994, A statisticaltopographic model for mapping climatological precipitation over mountainous terrain: Journal of Applied Meteorology, v. 33, p. 140-158.

Druse, S.A., 1991, Wyoming floods and droughts, in Paulson, R.W., Chase, E.B., Roberts, R.S., and Moody, D.W., comp., National water summary 1988-89, Hydrologic events and floods and droughts: U.S. Geological Survey Water-Supply Paper 2375, p. 575-582.

Dunne, T., and Leopold, L.B., 1978, Water in environmental planning: San Francisco, Calif., W.H. Freeman, 818 p. 
Emmett, W.W., 1975, The channels and waters of the upper Salmon River area, Idaho: U.S. Geological Survey Professional Paper 870-A, 115 p.

Harrelson, C.C., Rawlins, C.L., and Potyondy, J.P., 1994, Stream channel reference sites-An illustrated guide to field technique: U.S. Department of Agriculture Forest Service, Rocky Mountain Research Station, General Technical Report RM-245, 67 p.

Helsel, D.R., and Hirsch, R.M., 2002, Statistical methods in water resources: U.S. Geological Survey Techniques of Water-Resources Investigations, book 4, chap. A3, 510 .

Homer, C., Huang, C., Yang, L., Wylie, B., and Coan, M., 2004, Development of a 2001 national land cover database for the United States: Photogrammetric Engineering and Remote Sensing, v. 70, no. 7, p. 829-840, accessed September 29, 2009, at http://www.mrlc.gov.

Jobson, H.E., and Froehlich, D.C., 1988, Basic hydraulic principles of open-channel flow: U.S. Geological Survey Open-File Report 88-707, 150 p.

Krstolic, J.L., and Chaplin, J.J., 2007, Bankfull regional curves for streams in the non-urban, non-tidal Coastal Plain Physiographic Province, Virginia and Maryland: U.S. Geological Survey Scientific Investigations Report 2007-5162, 48 p., available at $h t t p: / / p u b s . u s g s . g o v /$ sir/2007/5162/.

Lawlor, S.M., 2004, Determination of channel-morphology characteristics, bankfull discharge, and various design-peak discharges in western Montana: U.S. Geological Survey Scientific Investigations Report 2004-5263, 19 p.

Leopold, L.B., 1994, A view of the river: Cambridge, Mass., Harvard University Press, 298 p.

Love, J.D., Christiansen, A.C., Brown, T.M., and Earle, J.L., comp., 1979, Preliminary geologic map of the Thermopolis $1^{\circ} \times 2^{\circ}$ quadrangle, central Wyoming: U.S. Geological Survey Open-File Report 79-962, scale 1:100,000.

Martner, B.E., 1986, Wyoming climate atlas: Lincoln, Nebr., University of Nebraska Press, $432 \mathrm{p}$.

McCandless, T.L., and Everett, R.A., 2002, Maryland stream survey-Bankfull discharge and channel characteristics in the Piedmont hydrologic region: U.S. Fish and Wildlife Service, Annapolis, Md., CBFO-S02-02, 41 p.

Miller, K.A., 1999, Surface water, in Zelt, R.B., and others, Environmental setting of the Yellowstone River Basin, Montana, North Dakota, and Wyoming: U.S. Geological Survey Water-Resources Investigations Report 98-4269, $112 \mathrm{p}$.
Miller, K.A., 2003, Peak-flow characteristics of Wyoming streams: U.S. Geological Survey Water-Resources Investigations Report 2003-4014, 79 p.

Mulvihill, C.I., and Baldigo, B.P., 2007, Regionalized equations for bankfull-discharge and channel characteristics of streams in New York State Hydrologic region 3 east of the Hudson River: U.S. Geological Survey Scientific Investigations Report 2007-5227, 15 p.

Nelson Engineering, 2004, Owl Creek master plan, level 1: Jackson, Wyo., report prepared for Wyoming Water Development Commission, variable pagination.

Ogle, K.M., 1992, Surface- and ground-water quality in the Owl Creek basin, north-central Wyoming: U.S. Geological Survey Water-Resources Investigations Report 91-4108, $65 \mathrm{p}$.

Perry, C.A., Aldridge, B.N., and Ross, H.C., 2001, Summary of significant floods in the United States, Puerto Rico, and the Virgin Islands, 1970 through 1989: U.S. Geological Survey Water-Supply Paper 2502, 598 p.

Powell, R.O., Miller, S.J., Westergard, B.E., Mulvihill, C.I., Baldigo, B.P., Gallagher, A.S., and Starr, R.R., 2004, Guidelines for surveying bankfull-discharge geometry and developing regional hydraulic-geometry models for streams of New York State: U.S. Geological Survey Open-File Report 03-92, $26 \mathrm{p}$.

PRISM Climate Group, Oregon State University: accessed February 24, 2010, at http://prismclimate.org.

Rosgen, D.L., 1996, Applied river morphology: Pagosa Springs, Colo., Wildland Hydrology, 388 p.

Rosgen, D.L., 2006, Watershed assessment of river stability and sediment supply (WARSS): Fort Collins, Colo., Wildland Hydrology, $648 \mathrm{p}$.

Rosgen, D.L., 2008, River stability field guide: Fort Collins, Colo., Wildland Hydrology, 264 p.

Stuckey, M.H., and Reed, L.A., 2000, Techniques for estimating magnitude and frequency of peak flows for Pennsylvania streams: U.S. Geological Survey Water-Resources Investigations Report 2000-4189, 20 p., plus appendixes.

Tasker, G.D., 1978, Relation between standard errors in log units and standard errors in percent: U.S. Geological Survey Water Resources Bulletin, January-March, April-June, p. $86-87$.

TIBCO Software, Inc., 2008, TIBCO Spotfire S+ 8.1 for Windows: Palo Alto, Calif., TIBCO Software, Inc., 572 p. 
U.S. Forest Service, 1995, A guide to field identification of bankfull stage in the western United States: Rocky Mountain Forest and Range Experiment Station, Stream Systems Technology Center, U.S. Department of Agriculture Forest Service, DVD-ROM, 31 minutes.

U.S. Geological Survey, 2009, User's manual for the national water information system of the U.S. Geological SurveyAutomated data processing system (ADAPS) U.S. Geological Survey version 4.9, accessed October 28, 2009, at http://nwis.usgs.gov/nwisdocs4_9/adaps/adaps.book.html.

U.S. Interagency Advisory Committee on Water Data, 1982, Guidelines for determining flood flow frequency, Bulletin 17-B of the Hydrology Subcommittee: Reston, Va., U.S. Geological Survey, Office of Water Data Coordination, 183 p., accessed September 25, 2009, at http://water.usgs.gov/osw/bulletin17b/butteting_17B.html.

Wahl, K.L, 1970, A proposed streamflow data program for Wyoming: U.S. Geological Survey Open-File Report, 44 p.
White, E.L., 1976, Role of carbonate rocks in modifying flood flow behavior: Water Resources Bulletin, v. 12, no. 2, p. 351-369.

White, K.E., 2001, Regional curve development and selection of a reference reach in the non-urban, lowland sections of the Piedmont Physiographic Province, Pennsylvania and Maryland: U.S. Geological Survey Water-Resources Investigations Report 01-4146, 20 p.

Wolman, M.G., 1954, A method of sampling coarse river-bed material: Transactions of the American Geophysical Union, v. 35 , no. 6 , p. $951-956$.

Wolman, M.G., and Miller, J.P., 1960, Magnitude and frequency of forces in geomorphic process: Journal of Geology, v. 68, p. 54-74.

Wyoming Department of Environmental Quality, 2007, Water quality rules and regulations, Chapter 1 , Wyoming Surface Water Quality Standards: Wyoming Department of Environmental Quality, Water Quality Division, Cheyenne, Wyoming. 



\section{Glossary}

The terms in this glossary were compiled from numerous sources. Some definitions have been modified for use within this report.

\section{B}

bankfull channel The active stream channel during the bankfull discharge.

bankfull discharge The stream discharge generally considered to be the single discharge that is most effective for moving sediment, forming or removing bars, and forming or changing bends and meanders, all of which result in the average morphological characteristics of channels (Dunne and Leopold, 1978).

bankfull mean depth The mean depth of the bankfull channel measured perpendicular to the streamflow.

bankfull-wetted perimeter The length, in feet, of the contact between the stream of flowing water and its containing channel, measured at a section perpendicular to streamflow at bankfull discharge.

bankfull width The width of the bankfull channel measured at a section perpendicular to streamflow at bankfull discharge.

\section{C}

coefficient of determination $\left(R^{2}\right)$ Measures the amount of variation in the bankfull response variable (bankfull cross-sectional area, discharge, width, or mean depth) that is accounted for by the variation in the explanatory variable (drainage area) (Helsel and Hirsch, 2002).

confidence interval (95-percent) The confidence interval represents a band within which there is a 95-percent probability that estimates of the mean bankfull-channel geometry or discharge for a particular drainage area will occur

cross-sectional area The cross-sectional area of the bankfull channel measured perpendicular to the streamflow.

\section{D}

DFFITS A measure of influence related to the studentized residuals (Helsel and Hirsch, 2002).

DGPS Differential Global Positioning System, a technique whereby data from a receiver at a known location is used to correct the data from a receiver at an unknown location. Differential corrections can be applied in real time or by post-processing. Since most of the errors in a global positioning system are common to users in a wide area, the DGPS corrected solution is significantly more accurate than a normal autonomous solution.

D $_{50}$ The geometric mean size of streambed particles as determined by measuring the intermediate axis of numerous particles on the streambed surface selected at random.

D $_{\text {s4 }}$ The particle size that is one standard deviation larger than the geometric mean particle size as determined by measuring the intermediate axis of numerous particles on the streambed surface selected at random.

drainage area The horizontal projection of the area upstream from a specific location that has a common outlet at the site for its surface runoff from precipitation that normally drains by gravity into a stream.

E

entrenchment ratio The vertical containment of the river described as the ratio of the flood-prone width to the bankfull width (Rosgen, 1996).

$\mathbf{F}$

flood-prone width The width across the flood plain, measured at a section perpendicular to the streamflow, at a water-surface elevation corresponding to twice the maximum depth of the bankfull channel (Rosgen, 1996). 


\section{G}

Global Positioning System (GPS) Passive, satellite-based navigation system operated by the Department of Defense of the United States. Its primary mission is to provide passive global positioning/navigation for land-, sea-, and air-based operations.

\section{M}

mean annual precipitation The basin average value for annual precipitation.

\section{$\mathbf{P}$}

prediction interval Represent a 95-percent certainty that an individual observed value of $\mathrm{y}$ for a given $\mathrm{x}$ will fall within the upper and lower limits of the interval (Helsel and Hirsch, 2002).

\section{R}

Real Time Kinematic (RTK) An algorithm run in a GPS receiver that allows its position to be determined in real time, with centimeter accuracy.

recurrence interval The average interval, in years, between exceedances of a particular annual peak discharge.

regional curve An ordinary least-squares regression expressed as a power function that relates drainage area to selected bankfull response variables. regulation A condition where streamflow is controlled by an upstream human-made feature.

residual standard error Measures the dispersion of the data around a regional curve and commonly is stated as the standard deviation of residuals (Helsel and Hirsch, 2002). Residual standard errors are not comparable between relations of different bankfull response variables and drainage area. For example, the residual standard error for the relation between cross-sectional area and drainage area cannot be compared directly to the residual standard error for the relation between bankfull mean depth and drainage area because the magnitude of cross-sectional area is much greater than bankfull mean depth.

Rosgen classification A system of describing river channels based on channel geometry, stream plan-view patterns, and streambed material (Rosgen, 1996).

\section{$\mathbf{T}$}

thalweg The lowest point in a stream channel.

W

width/depth ratio The ratio of bankfull width to bankfull mean depth measured at a section perpendicular to streamflow.
Publishing support provided by:

Denver Publishing Service Center, Denver, Colorado

For more information concerning this publication, contact:

Director, USGS Wyoming Water Science Center

521 Progress Circle, Suite 6

Cheyenne, WY 82007

(307) 778-2931

Or visit the Wyoming Water Science Center Web site at: http://wy.water.usgs.gov/

This report is available at: http://pubs.usgs.gov/sir/2012/5178 
